Конарівська О. Б., к.е.н., доцент; Коротун О. П., старший викладач (Національний університет водного господарства та природокористування, м. Рівне)

\title{
РОЛЬ ТА ОСОБЛИВОСТІ МАРКЕТИНГУ У СФЕРІ ТУРИСТИЧНИХ ПОслУг
}

Стаття присвячена вивченню зарубіжного та вітчизняного досвіду розвитку маркетингу туризму, визначені головні тенденції у сфері загального сучасного маркетингу. Проаналізовано підходи до визначення «маркетинг туристичних послуг» вітчизняними та зарубіжними вченими. Це дало змогу довести, що положення сучасного маркетингу можуть застосовуватись в туризмі та визначити його особливості у сфері туристичних послуг, а саме: суттєву залежність реалізації туристського продукту від місця та часу отримання, еластичність попиту, суб'єктивна оцінка якості послуг, а також відмінності в обслуговуванні, сезонність, особиста думка споживача та ін. Ключові слова: туризм, ринок туристичних послуг, маркетинг, попит, пропозиція, просування, туристичні послуги, маркетинг в сфері туристичних послуг.

Постановка проблеми. Сьогодні вітчизняний туризм забезпечує розвиток не тільки національної економіки, а й суміжних з ним галузей, сприяє зайнятості населення та поліпшенні роботи з охорони пам'яток природи, історії та культури, підвищує привабливість країни, створює стимули для залучення іноземного капіталу. Тобто, туризм виступає фундаментом для розвитку ринку туристичних послуг, який задовольняє потреби населення у відпочинку та змістовному проведенні дозвілля. Проте, його розвиток в Україні характеризується наявністю суттєвих системних проблем, головними серед яких $€$ скорочення матеріальної бази туристичної галузі та невідповідність туристичних послуг потребам населення. Інструментом для усунення зазначених проблем у сфері туристичних послуг виступає маркетинг, з допомогою якого стає можливим розпізнати, ідентифікувати і оцінити існуючий або прихований попит на туристичні послуги і спрямувати зусилля суб'єктів ринку туристичних послуг на розробку, виробництво, розподіл, продаж і просування туристичних товарів і послуг.

Тому вивчення особливостей маркетингу є актуальним завданням для вітчизняного ринку туристичних послуг. 
Аналіз останніх досліджень та публікацій. Дослідженням проблем маркетингу у сфері туристичних послуг приділили увагу багато вітчизняних та зарубіжних науковців, зокрема таких як О. Азарян, В. Боголюбов, Ж. Бодрійяр, Е. Вавилова, А. Дурович, Ф. Котлер, Н. Кудла, О. Любіцева, Ю. Правик, І. Смирнов, В. Шубаєва, Л. Шульгіна та ін. Водночас, особливості маркетингу у сфері туристичних послуг залишаються недостатньо вивченими на вітчизняному ринку туристичних послуг.

Метою статті є обґрунтування ролі маркетингу та визначення його особливостей у сфері туристичних послуг на основі закордонного і вітчизняного досвіду.

Виклад основного матеріалу. Розвиток маркетингу туристичних послуг від початку не був автономним, його теорія і практика перейняті з досвіду промисловості та торгівлі, а пристосування його до вимог туристичної індустрії було нелегкою справою. Таким чином, надбання науковців у сфері нематеріальних благ і послуг дозволили комплексно підійти до дослідження ринкових явищ у сфері маркетингу туристичних послуг. Для того, щоб визначити роль маркетингу та визначити його особливості у сфері туристичних послуг, потрібно звернутися до вивчення досвіду закордонних та вітчизняних науковців із зазначеної проблематики.

Вивчення зарубіжного досвіду дав змогу виокремити основні такі тенденції у сфері загального сучасного маркетингу [9-10]:

- створення нових продуктів і формування попиту на них шляхом просування і популяризації технологій їх споживання;

- залучення не тільки нових покупців, а перетворення наявних у лояльних;

- використання краудсорсингу в режимі он-лайн;

- створення контенту для соціальних медіа та зростання їх використання як нового інструменту комунікацій;

- організація діяльності підприємства у такий спосіб, щоб споживачі самі були зацікавлені шукати і створювати інформацію про бренд;

- використання коаліційних мультибрендових програм;

- визнання культурних відмінностей між національностями;

- посилення ролі персоналу.

Стосовно ж маркетингу туристичних послуг Ф. Котлер, Дж. Боуен, Дж. Мейкенз зазначають, що це керований соціальний процес, за допомогою якого індивідууми і групи людей придбають те, в чому відчувають потребу, і що хочуть отримати в процесі обміну з іншими створеними продуктами і цінностями [3, С. 16]. 
Група науковців А. Дайан, Ф. Буккерель, П. Ланкар та ін. визначають маркетинг туристичних послуг як основні методи і прийоми, що застосовуються для дослідження, аналізу та вирішення поставлених завдань, які повинні спрямовуватись на виявлення можливостей повного задоволення потреб споживачів з погляду на психологічні, соціальні фактори, а також на визначення способів найбільш раціонального з фінансової точки зору ведення справ туристичного підприємства, яке дозволяє врахувати виявлені чи приховані потреби в туристичних послугах [1, С. 288].

В. Кифяк визначає маркетинг туристичних послуг як систему координації діяльності туристичного підприємства у процесі розробки, виробництва, реалізації туристичного продукту та послуг з метою отримання максимального прибутку шляхом найбільш повного задоволення споживача [2, С.189].

Н. Кудла дає розширене визначення маркетингу туристичних послуг, зазначаючи, що це «комплекс заходів, пов'язаних із визначенням і розробкою туристичного продукту, а також його просуванням відповідно до психологічних та соціальних факторів, які необхідно враховувати для задоволення потреб індивідуумів і груп людей у відпочинку, розвагах за допомогою надання їм житла, транспортних засобів, харчування, організації дозвілля тощо. Маркетинг у туризмі $є$ системою вивчення туристичного ринку, всебічного впливу на покупця, його запитів з метою надання максимальної якості туристичному продукту і одержання прибутку туристичною фірмою» [4].

Такої ж думки дотримується і Ю. Правик, визначаючи маркетинг туристичних послуг як комплекс заходів, пов'язаних із визначенням, розроблення і просуванням туристичного продукту [6, С. 71].

Якщо у першому визначенні маркетинг туристичних послуг подається, як методи і прийоми, спрямовані на виявлення можливостей повного задоволення потреб споживачів, то у другому й третьому - це заходи щодо визначення, розробки і просування туристичного продукту.

3 означеного випливає, що різні науковці мають різне бачення сутності маркетингу туристичних послуг і не включають до його складу головних елементів, що було б доцільно зазначити у визначенні. Вважаємо за необхідне з'ясувати які ж існують особливості застосування елементів маркетингу в туристичній діяльності.

Чітко до цього питання підійшли науковці О. Тєлєтов та Н. Косолап, які включають такі чотири елементи [8, С. 23]:

1. Товар (якість, категорія, товарна марка, асортимент послуг);

2. Ціна (діапазон, цінові знижки, умови оплати, співвідношення ціна/якість); 
3. Розподіл (розташування, доступність, покриття послугою);

4. Маркетингові комунікації (реклама, персональний продаж, прямий маркетинг, PR).

Науковці О. Будя, О. Вертелєва пропонують враховувати особливості кожної галузі як виробничої, так і невиробничої сфери при розробці комплексу маркетингу підприємств туристичного бізнесу та виділяють такі складові елементи [1 1, С. 83]:

1. Програмування (programming) - це різновид проектної діяльності щодо створення туристичного продукту, який здійснюється в декілька етапів: від розробки загальної концепції турів до об'єднання товарів і послуг у тур;

2. Комплектування (packing) - заключний етап проектування, в процесі якого туристичний продукт набуває комплексності за рахунок співвідношення всіх елементів, які задовольняють рекреаційні, пізнавальні, оздоровчі та інші потреби мандрівника;

3. Партнерство (partnership) - це результат роботи підприємств (принципи роботи, специфічні потреби, комерційні цілі) по розробці туристичного продукту.

А. Дурович вказує на ще один важливий елемент маркетингу у сфері туристичних послуг - методику інформування, що $\epsilon$ невід'ємною частиною загальної методики ведення туристичного бізнесу [12, C. 34].

В західних компаніях існує чіткий термін «виграти клієнта». Це означає надати йому відповідні умови не тільки для відпочинку, а й реалізації всіх етапів від пошуку до оплати і обслуговування. Аналізуючи процес ведення туристичного бізнесу, слід підкреслити важливість усього ланцюга: реклама і просування продукту, пошук і підбір послуги, бронювання, продаж, оформлення документів, гарантії, оплата, остаточні взаєморозрахунки [13, С. 51].

Таким чином, дослідження зарубіжного та вітчизняного досвіду стосовно зазначеної проблематики, дало змогу виявити особливості послуг у сфері туризму:

- нематеріальність - туристичні послуги існують лише в процесі їх надання та споживання;

- неможливість зберігання - надання і споживання послуги відбуваються одночасно, ані туристичні підприємства, ані споживач туристичних послуг не в може створювати запаси цих послуг;

- невіддільність від постачальника туристичних послуг або навколишніх умов - надання послуги передбачає прямий контакт 3 особою, яка надає послугу або з представником сервісної організації;

- унікальність - на відміну від того, що більшість виробів стан- 
дартизовані або мають стандартизовані компоненти, кожна туристична послуга $є$ унікальною.

В цілому вважаємо, що послуги у сфері туризму є такими ж, як й інші форми надання послуг, тому положення сучасного маркетингу можуть застосовуватись і в туризмі. На підтвердження цієї думки, проілюструємо особливості, що притаманні туристичним послугам на ринку у порівнянні з іншими послугами (рисунок).

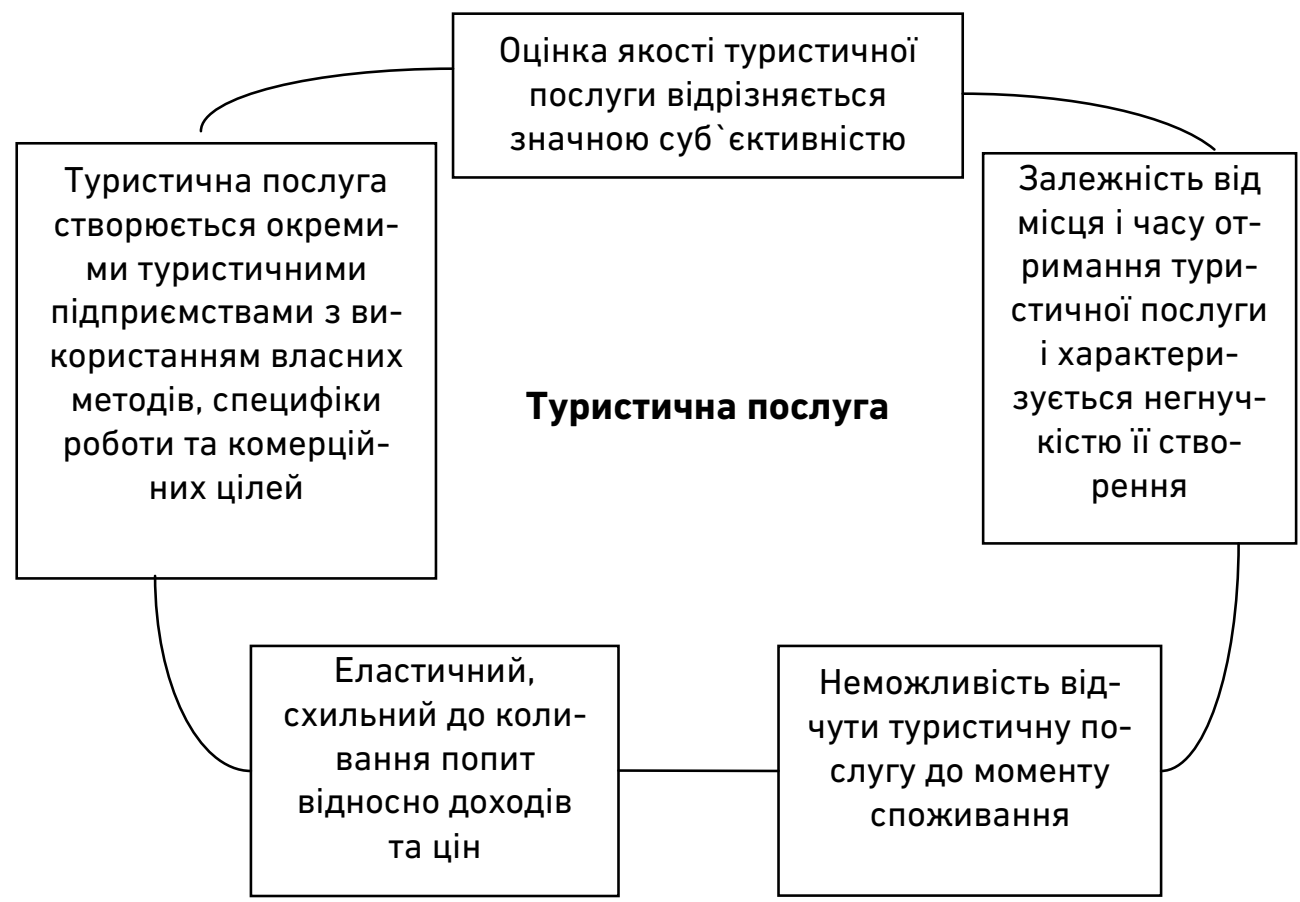

Рисунок. Специфіка туристичної послуги на ринку туристичних послуг Джерело: узагальнено авторами на основі [8, С. 24].

3 приведеного рисунка видно, що туристична послуга є специфічною, відмінною від інших послуг, що надається суб'єктами туристичних послуг - туристичними підприємствами на ринку туристичних послуг.

Ю. Правик у своєму підручнику «Маркетинг туризму» більш ширше характеризує означену специфіку, зокрема: «...треба враховувати, що попит на туристичні послуги певної території також багато в чому залежить від властивих їй політичних та соціальних умов. Здебільшого людина не може побачити турпродукт до споживання, яке здійснюється безпосередньо в місці створення. Користувач долає відстань, що відділяє його від продукту і місця споживання, а не навпаки. Не можна досягти високої якості туристичних послуг за наявності навіть незначних недоліків в обслуговуванні, оскільки саме дрібні деталі складають основу конкурентоспроможності в туристич- 
ній сфері. На оцінку якості туристичної послуги великий вплив справляють особи та чинники, що не відносяться до пакета послуг (місцеві жителі, члени туристичної групи, спонтанні політичні обставини). Задоволеність послугою залежить і від зовнішніх факторів, які мають, як правило, форс-мажорний характер (природні умови, міжнародні події тощо) [6, С. 73].

Таким чином доведено, що туристичні послуги є специфічними і відмінними від інших послуг на ринку. Ми схиляємось до думки науковців [8, С. 33] стосовно того, що маркетинг у сфері туристичних послуг має властивості маркетингу послуг й специфічні особливості.

Висновки й перспективи подальших досліджень. У статті, на основі зарубіжного та вітчизняного досвіду, визначені головні тенденції у сфері загального сучасного маркетингу, зокрема: створення нових продуктів і формування попиту на них шляхом просування і популяризації технологій їх споживання; залучення не тільки нових покупців, а перетворення наявних у лояльних; використання краудсорсингу в режимі он-лайн; створення контенту для соціальних медіа та зростання їх використання як нового інструменту комунікацій; організація діяльності підприємства у такий спосіб, щоб споживачі самі були зацікавлені шукати і створювати інформацію про бренд; використання коаліційних мультибрендових програм; визнання культурних відмінностей між національностями; посилення ролі персоналу. Доведено, що послуги у сфері туризму є такими ж, як й інші форми надання послуг, тому положення сучасного маркетингу можуть застосовуватись і в туризмі.

Таким чином, до головних особливостей маркетингу у сфері туристичних послуг можна віднести такі: значну залежність реалізації туристичного продукту від місця та часу отримання; еластичний попит, що залежить від політичних та соціальних умов; суб'єктивну оцінку якості послуг, а також відмінності в обслуговуванні, сезонність, особиста думка споживачів та ін.

1. Академия рынка : маркетинг. / А. Дайан, Ф. Буккерель, П. Ланкар и др. / пер. с фр. Москва : Экономика, 1993. 572 с., С. 288. 2. Кифяк В. Ф. Організація туристичної діяльності в Україні. Чернівці : Зелена Буковина, 2003. 312 с., С. 189. 3. Котлер Ф., Боуен Дж., Мейкенз Дж. Маркетинг. Гостеприимство и туризм: учебник/ пер. с англ. Москва: ЮНИТИ, 1998. 787 с., С. 16. 4. Кудла Н. Є. Маркетинг туристичних послуг. Київ : Знання, 2011. 351 с. 5. Любіцева О. О. Ринок туристичних послуг. Київ: Альтерпрес, 2005. 436 с. 6. Правик Ю. М. Маркетинг туризму : підручник. Київ : Знання, 2008. 303 с., С. 71. 7. Ринки туристичних послуг: стан і тенденції розвитку : монографія / за заг. ред. професора В. Г. Герасименко. Одеса : Астропринт, 2013. 334 с. 
8. Тєлєтов О. С., Косолап Н. Є. Особливості та перспективи маркетингу туристичних послуг в Україні. Маркетинг і менеджмент інновацій. 2012. № 1. C. 21-34. 9. Roth P. Touristik Marketing. Aufl. München : Vahlen, 1995. 210 s. 10. Seitz E., Wolf J. Tourismusmanagement und - marketing. Landsberg / Lech, 1991. 219 s. 11. Будя О. П., Вертелєва О. В. Інноваційні напрямки розвитку маркетингу в сфері туризму і гостинності. Зовнішня торгівля : право та економіка. 2008. № 6. С. 142-149. 12. Дурович А. П. Маркетинг туризма. Минск: Финансы, учет. Аудит, 2010. 320 с. 13. Бурдонос Л. І. Особливості маркетингу туристичних підприємств в Україні. Економічний вісник університету. 2013. Вип. 20(1). С. 48-53.

\section{REFERENCES:}

1. Akademiia rynka : marketinh. / A. Daian, F. Bukkerel, P. Lankar i dr. / per. s fr. Moskva : Ekonomika, 1993. 572 s., C. 288. 2. Kyfiak V. F. Orhanizatsiia turystychnoi diialnosti v Ukraini. Chernivtsi : Zelena Bukovyna, 2003. 312 s., C. 189. 3. Kotler F., Bouen Dzh., Meikenz Dzh. Marketinh. Hostepriimstvo i turizm : uchebnik / per. s anhl. Moskva : YuNITI, 1998. 787 s., C. 16. 4. Kudla N. Ye. Marketynh turystychnykh posluh. Kyiv : Znannia, 2011. 351 s. 5. Liubitseva 0. 0. Rynok turystychnykh posluh. Kyiv : Alterpres, 2005. 436 s. 6. Pravyk Yu. M. Marketynh turyzmu : pidruchnyk. Kyiv : Znannia, 2008. 303 s., S. 71. 7. Rynky turystychnykh posluh: stan i tendentsii rozvytku : monohrafiia / za zah. red. profesora V. H. Herasymenko. Odesa : Astroprynt, 2013. 334 s. 8. Tielietov 0. S., Kosolap N. Ye. Osoblyvosti ta perspektyvy marketynhu turystychnykh posluh v Ukraini. Marketynh i menedzhment innovatsii. 2012. № 1. S. 21-34. 9. Roth P. Touristik Marketing. Aufl. München : Vahlen, 1995. 210 s. 10. Seitz E., Wolf J. Tourismusmanagement und - marketing. Landsberg / Lech, 1991. $219 \mathrm{~s}$. 11. Budia O. P., Vertelieva O. V. Innovatsiini napriamky rozvytku marketynhu v sferi turyzmu i hostynnosti. Zovnishnia torhivlia : pravo ta ekonomika. 2008. № 6. S. 142-149. 12. Durovich A. P. Marketinh turizma. Mynsk : Finansy, uchet. Audit, 2010. 320 s. 13. Burdonos L. I. Osoblyvosti marketynhu turystychnykh pidpryiemstv v Ukraini. Ekonomichnyi visnyk universytetu. 2013. Vyp. 20(1). S. 48-53.

Рецензент: д.е.н., професор Мальчик М. В. (НУВГП)

Konarivska O. B., Candidate of Economics (Ph.D.), Associated Professor;

Korotun O. P., Senior Lecturer (National University of Water and

Environmental Engineering, Rivne)

\section{ROLE AND FEATURES OF MARKETING IN THE SPHERE OF TRAVEL SERVICES}

The article is devoted to the study of foreign and domestic experience 
in the development of tourism marketing, identifies the main trends in the field of general modern marketing. Analyzed approaches to the definition of "marketing tourism services" by domestic and foreign scientists. This made it possible to draw conclusions that the provisions of modern marketing can be applied in tourism and determine the features of these provisions in the field of tourism services, namely: a significant dependence of the implementation of a tourist product on the place and time of receipt, the elasticity of demand, a subjective assessment of the quality of services, as well as differences in service, seasonality, personal opinion of consumers, etc.

Keywords: tourism, tourism services market, marketing, demand, supply, promotion, tourism services, tourism marketing.

Конаривска О. Б., к.э.н., доцент; Коротун О. П., старший преподаватель (Национальный университет водного хозяйства и природопользования, г. Ровно)

\section{РОЛЬ И ОСОБЕННОСТИ МАРКЕТИНГА В СФЕРЕ ТУРИСТИЧЕСКИХ услуг}

Статья посвящена изучению зарубежного и отечественного опыта развития маркетинга туризма, определены основные тенденции в сфере общего современного маркетинга. Проанализированы подходы к определению «маркетинг туристических услуг» отечественными и зарубежными учеными. Это позволило сделать выводы о том, что положения современного маркетинга могут применяться в туризме и определить особенности этих положений в сфере туристических услуг, а именно: значительную зависимость реализации туристического продукта от места и времени получения, эластичность спроса, субъективную оценку качества услуг, а также отличия в обслуживании, сезонность, личное мнение потребителей и др.

Ключевые слова: туризм, рынок туристических услуг, маркетинг, спрос, предложение, продвижение, туристические услуги, маркетинг в сфере туристических услуг. 